\title{
The Representation of Basuki Tjahaja Purnama (BTP) as a Social Actor in the Collection of Hoax News Headlines on www.turnbackhoax.id
}

\author{
Zakie Asidiky', R. Vindy Melliany Puspa ${ }^{2}$ \\ 1,2Sekolah Tinggi Bahasa Asing YAPARI-ABA, Bandung, Indonesia \\ 'Email: asidiky@stba.ac.id
}

Submitted: 29/11/2019

Revised: 07/12/2019

Accepted: $16 / 01 / 2020$

\begin{abstract}
This study aims to describe the representation of Basuki Tjahaja Purnama (BTP) as a social actor and to reveal the ideological stance of the media in collection of hoax news headlines. The approach used in this study is Fairclough's three-dimensional model of critical discourse analysis $(1995,2013)$ with a textual metafunction theory as its analytical tool proposed by Halliday and Mattiessen (2014). The data of this study are 17 hoax news headlines that have been verified by their lies on the website www.turnbackhoax.id. The results of this study are (i) the theme and rheme used in the hoax news headlines can help organize messages and play an important role in the headlines from the perspective of the reader, (ii) BTP was explicitly represented as a social actor in some negative ways in those hoax news headlines such as he is supported by those who are not Pro-Islam, fails to eradicate prostitution, powerful person, not brave and involved in law case, (iii) the media's ideological stance intentionally contradicted to other national media in publishing the hoax news headlines related to BTP and tended to highlight the news without the clear sources and exaggerate the headlines. Furthermore, the result of this study would be a helpful material source for those who would like to prepare the critical literacy materials, specifically, about how to identify the features of hoax news headlines.
\end{abstract}

Keywords: Critical Discourse Analysis (CDA), Hoax News Headlines, Ideological Stance, Representation.

https://ojs.unm.ac.id/eralingua

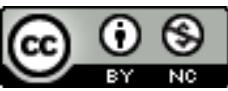

This work is licensed under a Creative Commons Attribution-NonCommercial 4.0 International License. 


\section{INTRODUCTION}

Before Jakarta's governor election for period 2017-2022 held in April 2017, the hoax news headlines about Basuki Tjahaja Purnama (hereinafter BTP) were widely circulating on social media platforms. Nevertheles, those headlines were succesfully identified by the Indonesian police cyber team. Generally speaking, a news headline itself is an important part of news since the reader will firstly see it before actually reading the whole news. If the headline is interesting, then the news text will most likely be read to completion by readers (Rolnicki, 2008).

Meanwhile, BTP or also known as 'Ahok' was Jakarta's first non-Muslim governor in last 50 years after taking over the governor position from Joko Widodo (hereinafter Jokowi) in 2014 after he had been officially elected as Indonesian President period 2014-2019 at time. BTP then served as Jokowi's deputy until 2017. Yet, in April 2017, he lost in the Jakarta's governor election for period 2017-2022 amid a blasphemy case and in May 2017 he was found guilty and sentenced to two years in prison for the case and inciting violence. He was accused of mocking a verse in the Koran, Al-Maidah 51 that had been used by his opponents to argue that Muslims should not vote for a non-Muslim leader. He consistently denied blasphemy, saying his comments were aimed at politicians who incorrectly used the Koran against him. Before the controversy, BTP had been widely hailed as a straighttalking politician with a strong anti-corruption stance (BBC, 2017)

In this study, the authors aim to analyze how the hoax news headlines represented BTP and to reveal the ideological stance of the media that published those hoax news headlines using Critical Discourse Analysis (hereinafter CDA). CDA is an empirical approach used to study discourse in social and political contexts. Moreover, CDA can also present issues such as gender, ideology and identity and how they are reflected in certain texts (Paltridge, 2012). What is said by Paltridge is in accordance with the function of language proposed by Fairclough (1995) which views that language is a practice of power and carries a certain ideological value. Furthermore, Wodak and Mayer in Mogashoa (2014) argue that CDA emphasises the need for interdisciplinary work in order to gain a proper understanding of how language functions in constituting and transmitting knowledge in organizing social institutions.

Talking about ideology, Chiapello (2012) states that in general, ideology, from a critical side, can be defined as a collection of ideas or beliefs that are systematic. In addition, the relationship between power domination can refer to the representation of certain ideologies. Meanwhile, Systemic Linguistic Functional (SLF) views that the language used, both written and oral, contains 3 (three) language metafunctions. SFL is both a theory and a method for the investigation of language in sociocultural contexts (Heberle, 2016). The functional language approach views that text has three functions. They are ideational, interpersonal, and textual. Halliday in Fairclough (2003: 27) argues that the text represents aspects of the world (physical world, social world, and mental world) and makes social relations between participants in social events and participants' attitudes, desires and values clearly (coherently) and integrated (cohesion) that connects each part of 
the text simultaneously and connects the text with the context of the situation. SFL also uses model of language as social context LSF (Santosa, 2016).

Related to this study, there are some previous studies discussed about BTP. Among them, Tulus (2017) with the research title "Discourse on Allegations of Defamation of Religion by Basuki Tjahja Purnama (Ahok)" (Norman Fairclough's Critical Discourse Analysis in News in the Headline of Republika Newspaper). According to finding result from her analysis on the Republika Headline news about religion abusement case by Basuki Tjahaja Purnama (Ahok), and the interview with informant, show that: (1) According to the text there are many words represented for judging Basuki Tjahaja Purnama (Ahok); (2) In informing the Basuki Tjahaja Purnama (Ahok) case, Republika has a role as Muslim media community; (3) because of Republika's role as Muslim media community, so in informing that news, it concern with Muslim community, although like that Republika still objective with the other facts; (4) From Sociocultural practice there are situational, institutional and social aspects that influenced in making news, because Republika's market is Muslim community from the middle to upper class.

Moreover, Amelda (2018) in her thesis entitled Representation of Basuki Tjahaja Purnama (Ahok) in the 2017 DKI Governor Election Process (A Study of Critical Discourse Analysis) on the website www.mediaindonesia.com revealed Ahok's representation in the election process of DKI Jakarta in the online media portal using van Dijk's CDA framework. The results of her thesis have shown that online website has a tendency to be on the pro side of the news Ahok. This is shown by representing Ahok more dominantly than other candidates.

So, the different things between this study and the previous studies are (1) in this study, we applied the Halliday's textual metafunction as the analytical tool to represent BTP as social actor and the ideological stances of hoax disseminating media and (2) the data was taken from the hoax news headlines about Basuki Tjahya Purnama (BTP). The authors chose BTP as the object of the study because at time, he was the governor of DKI Jakarta where the central place of the government in Indonesia is located. Moreover, he had also a case related to the issues of ethnicity, religion, race, and inter-group relations. Those issues then had become discourses built that were intended to overthrow his government.

\section{RESEARCH METHOD}

This research uses the discourse analysis method with a critical approach or also known as the critical discourse analysis (CDA) method. Badara (2012) states that a critical approach is an approach that focuses the attention on dismantling aspects that are hidden behind a reality that appears to do criticism and changes to social structure. He also considers that the critical approach views that the reality seen is a pseudo reality that is influenced by social, political, cultural, economic, ethnic, gender values and others that have crystallized over a long period of time.

In CDA, the analysis will focus on linguistic aspects and the contexts related to linguistic aspects. These contexts can be interpreted as aspects of language that are used for certain social goals or practices. The CDA method in this study aimed to describe the representation of Basuki Tjahaja Purnama (BTP) in the hoax news headline on the website www.turnbackhoax.id and the ideological stance of the 
media in spreading hoax news about BTP. The CDA model used in this study is the CDA model proposed by Norman Fairclough (2013). The Fairclough CDA method is known as a three-dimensional CDA method.

Fairclough's three-dimensional framework includes a conception of discourse as a text or micro level, discourse practice or meso level and sociocultural practice or macro level (Shojaei, 2013 ; Yousefi, 2019). In the micro level, the authors describe how the media's linguistic strategy in reporting BTP on the hoax news headlines using Halliday's textual metafunction theory. In the meso level, the authors interpret the origin of the discourse production and consumption. While, in the sociocultural practice, the authors explain, first, the kinds of discourse built from the use of those headlines and, second, how BTP is portrayed as a social actor in the discourses built from those headlines.

The source of the data in this study was a collection of hoax news headlines on the website www.turnbackhoax.id which discussed BTP from January 2016 to November 2017. Data were collected online from hoax news headlines that have been verified in a special website about hoax news. The numbers of data analyzed were 17 hoax news headlines.

\section{RESULT AND DISCUSSION}

Having analyzed the data with Fairclough's three dimensional model of CDA, the authors have successfully identified the analyses of micro, meso and macro. Of the micro analysis, the authors identified the textual metafunction in 17 hoax news headlines used as data sources. There are two types of themes identified in the data. They are topical theme with 12 data or $70.58 \%$ and interpersonal theme with 5 data or $29,42 \%$. Functionally speaking, the themes used in those hoax news headlines help organize messages and play an important role to give information to readers. Those themes also help interpret the intended interpretation of the overall headlines.

In the discourse practice analysis, the hoax news headlines had been produced by, we tend to use the term, an unpopular publishers as they are not trusted and difficult to find out the accurate sources that foregrounding their published headlines. Those publishing media seem to be moved by certain groups backed by those who have sufficient financial supports with, of course, the certain political intentions. Furthermore, in the context of text consumption, those headlines were intended to be comsumed by the readers, particularly those who did not have the critical thinking ability that tend to take the information on the headlines for granted easily.

While, In the socio-cultural practice, the hoax news headlines were trying to build the political discourses that more focused on the efforts of influencing readers not to vote BTP in the Jakarta's governor election held in April 2017 through the sentiments of ethnicity, religious belief, law case, and other illogical things. Those built discourses also socially function to negatively portray or represent BTP as a social actor. 


\section{The Representations of BTP on Hoax News Headlines}

Of the analyses of micro, meso and macro, we have identified that BTP was negatively represented as a social actor in those headlines. The representation of BTP in the hoax news headlines is different from his representation as a social actor in another study conducted by Amelda (2018) that took articles from Media Indonesia website as her data source. In her study, BTP was portrayed in some positive ways as social actor and the media indonesia's ideological stance was proBTP. Meanwhile, in the study conducted by Setyaningsih (2017) that took article from media Republika as the data of study, BTP was judged negatively in that article. Although Republika's ideological stance is more toward the Muslim media community, the news discussing BTP was published in a neutral or an objective way.

As we stated earlier that BTP was represented in the negative ways in the hoax news headlines, we identified his detail representation as a social actor as follows:

\section{a. BTP as a social actor who were supported by many parties}

BTP was represented as a social actor supported by many parties from within or outside the country. The representation was identified from the use of themes of following 5 hoax news headlines. The five headlines are as follows:

(i) 50\% atau kurang lebih 5 juta orang (forum) gerakan buruh Jakarta mendukung Ahok

$50 \%$ or approximately 5 million people (forum) of the Jakarta labor movement support Ahok.

(ii) 500 WN China Datang ke Jakarta untuk Bela Ahok 500 Chinese citizens came to Jakarta to support Ahok

(iii) Kami Siap Bunuh Diri Jika Pak Ahox Kalah Dalam Pilkada 2017 We are ready to suicide If Mr Ahox looses In the Governor Election 2017

(iv) Kalau Non Muslim tidak boleh menjadi Gubernur DKI atau presiden Indonesia maka biarkan Papua Melanesia Merdeka

If Non-Muslims cannot become the Governor of Capital Special Region or the president of Indonesia, then let Papua Melanesia be free.

(v) German Siapkan Transisi Ahok untuk jadi walikota di Berlin jika pemerintah bersedia! Ini faktanya.

Germany Prepares Ahok's Transition to become mayor in Berlin if the government is willing! This is the fact.

The themes in the 5 headlines are (1) $50 \%$ atau kurang lebih 5 juta orang (forum) gerakan buruh Jakarta (50\% or approximately 5 million people (forum) of the Jakarta labor movement), (2) 500 WN China (500 Chinese citizens), (3) Kami (We), (4) Kalau Non Muslim tidak boleh menjadi Gubernur DKI atau presiden Indonesia (If Non-Muslims cannot become the Governor of Capital Special Region or the president of Indonesia), (5) German (Germany).

From the theme and the rheme used in the headline (i), BTP was represented as a social actor who was supported by almost half of the workers who were affiliated 
in the Jakarta labor movement. The theme and rheme in headline (ii) identified that BTP was represented as a leader who was also defended by 500 Chinese citizens. The theme and rheme of the headline (iii) identified the group who was ready to suicide If Mr. Ahok lost in the governor Election 2017. In headline (iv) BTP was represented as a social actor who would be supported by sympathizers from NonMuslims. Meanwhile, in headline (v), BTP was represented as a leader who would be supported by the German government. The authors can say that the use of the themes in the five headlines have given the first impression at the first sight to readers when reading the headlines.

\section{b. BTP is a social actor who was not pro-Islam}

BTP was represented as a social actor who was Anti-Islam. The representation was identified from the use of the themes of the 4 hoax news headlines from this research data. The four headlines are as follows:

(vi) "Kamu Kira Kami Niat Bangun Masjid dan Naikkan Haji Marbut"

"You think we intend to build a Mosque and Raise Marbut Hajj"

(vii) "Sekarang kristenisasi pake APBD"

"Now christianization uses the regional budget"

(viii) "Mujahid Cyber Membela KPU Dari Serangan Hacker Ahok"

"Cyber mujahid defends general election commissions from Ahok's haker attack"

(ix) "Jika Kami Menang Gereja di Jakarta Harus Lebih Besar dari Istiqlal"

"If we win a church in Jakarta must be bigger than Istiqlal"

The themes in the headlines above are (vi) Kamu (You), (vii) Sekarang Kristenisasi (Now Christianization), (viii) Mujahid Cyber (Cyber Mujahid), and (ix) Jika Kami Menang (If we win).

In the headline (vi), BTP was represented as a social actor who was not proIslam because he did not want to build a mosque and did not pay attention to Marbut with quoting what was said by BTP regarding the construction of houses of worship for Muslims. Similar to the headline (vi), the headline (vii) also seems to quote what was said by BTP regarding the spread of Christianity by using the Regional Budget Development Fund (APBD). In the headline (viii), BTP was represented as having a hacking team to hack the General Election Commissions (indoneisian: KPU) to secure votes and even win Jakarta's regional election in 2017. Meanwhile, in headline (viii) cyber mujahid would protect the General Election Commissions from the BTP hackers team. In the headlines (ix), similar to the headlines (vi) and (vii), BTP was represented as an anti-Islam figure by means of, as if, quoting what BTP had said about what he would do to make church in Jakarta bigger than Istiqlal if he won the 2017's elections.

\section{c. BTP as a social actor who failed to eradicate prostitution}

BTP was represented as a social actor who failed to eradicate prostitution in Jakarta identified from the following headlines.

(x) Era Jokowi-Ahok Makin Menjamur PSK 
In the Era of Jokowi-Ahok the number of prostitutes increases more and more. (xi) PSK Asal Cina di Jakarta Raup Rp 40 Miliar/Bulan

The Prostitutes from China in Jakarta receive Rp. 40 Billion/Month

The theme of the headline (x) is Era Jokowi-Ahok (The Era of Jokowi-Ahok). Meanwhile, the theme used in the headline (xi) was PSK asal China di Jakarta (The prostitues from China in Jakarta). In the headlines ( $x$ ) and (xi), BTP was represented as a social actor who failed to eradicate the prostitution in Jakarta.

\section{d. BTP as a social actor whose power to move things}

BTP was represented as a social actor who had a super power identified from the use of the themes from the headline below;

(xii) Bagaimana Ahok dan Djarot memindahkan pohon dalam rangka pembangunan Semanggi

How Ahok and Djarot moved trees when Semanggi's development

The theme of the headline (xii) is Bagaimana Ahok dan Djarot (How Ahok and Djarot). In this headline BTP and his candidate of vice governor, Djarot, were represented as social actors that could move trees without having to damage them in Semanggi's devolpment.

\section{e. BTP as a social actor who is not dare}

BTP was represented as a social actor who was not brave to progress

(xiii) Kalau Ahok Maju Via Jalur Independen, Saya Rela Menari Bugil di Monas If Ahok nominates via independent pathway, I want to dancing naked at Monas

(xiv) Lembaga Anti Hoax Koq Akan Dibuat Mabes Polri Bersama Teman ahok the Anti-Hoax Institution will be made by the national police headquarter with Ahok's Friends

There are two themes in headline (xiii). They are Kalau Ahok (If Ahok) and Saya (I). Meanwhile, the theme of Headline (XIV) is Lembaga Anti-Hoax (Anti-Hoaks Institution). The headlines (xiii) and (xiv) were represented BTP as a social actor whose a role as a governor candidate who would not dare to go forward through independent way and the leader has supporters who have direct access to the police of the Republic of Indonesia.

\section{f. BTP as a social actor who involved in the law cases}

BTP was represented as a social actor who involved in the law cases identified from the use of the themes from the following headlines;

(xv) Bocoran Nama-Nama Penerima Gratifikasi Proyek eKTP terdapat Nama Ahok

The Leaked Names of Recipients in the eKTP Project Gratification. There is a name, Ahok.

(xvi) Suku Baduy Menuntut Ahok Dipenjara 5 Tahun 


\section{Baduy tribe demands ahok to be imprisoned for 5 years}

The theme of the headline (xv) is bocoran Nama-Nama Penerima Gratifikasi Proyek eKTP (the Leaked Names of Recipients in eKTP Project gratification). Meanwhile, the theme of the headline (xvi) is suku baduy (Baduy Tribe). Those headlines (xv) and (xvi) function to represent BTP as a candidate for governor who has problems with the law.

\section{g. BTP as a social actor who changes his religious belief (an islamic convert)}

BTP is represented as an islamic convert from the following headline;

(xvii) Ahok Mengucapkan Dua Kalimat Syahadat, Ketua FPI Pun Meneteskan Air Matanya

When Ahok was saying two sentences of creed, the Chairperson of FPI was also tearing.

There are two themes of the headline xvii. They are Ahok or also know as BTP and the chairperson of FPI (a NGO in Indonesia, abbreviated for Islamic Defenders Front). This headline tried to represent BTP as a social actor who had embraced Islam and was greeted with tears of emotion by the head of one of the Islamic community organizations.

\section{The Ideological stance of the media}

Theory of ideology is perceived as a multidisciplinary approach which is the fundamental framework for organizing multiple ideological concepts and consumptions. Ideologies usually control the thoughts of a social group which then represent the basic social characteristics of a group based on their identities, goals, values, positions and resources. The media's ideological stance can be contradicted to other national media, specifically, in publishing the hoax news headlines related to BTP and tended to highlight the news without the clear sources and exaggerate the headlines. Its contradiction can be represented in the headlines used that tend to (1) provoke readers, (2) disfigure readers, (3) understate BTP and (4) overstate BTP.

To provoke, in Indonesian, is defined as acts to arouse anger; incitement; inducement. Meanwhile, In Cambridge Advanced Learner's Dictionary (hereinafter (ALD) to provoke means to cause a reaction, especially a negative one or make angry. In the data, the provocative headlines are identified in the hoax news headline no (i), (ii), (iv), (viii), (ix) and (xvi). To disfigure, in Bahasa, means to spoil the appearance of something or someone, especially their face completely. The indicated disfiguring headlines are in headlines (vii), (x), (xi) and (xv). To underestimate in CALD id defined as to fail to understand how strong, skilful, intelligent or determined someone, especially a competitor is. The underestimating or exaggerating headlines are (xii) and (xiii) which was focused on as if there is an assumption that something is impossible to do. To overstate, in Bahasa, means to express or state too strongly; exaggerate. In this case, it can be identified in headlines (iii), (v), (vi) (xiv) and (xvii). 


\section{CONCLUSION}

This study has shown that the hoax news headlines had played a significant role in the production of readers' beliefs, prejudice and domination over them, particularly, in marginalizing BTP as a social actor. It was found that ever since CDA has gained popularity in the field of discourse studies, an increasing number of studies has applied CDA to investigate the different perspective of text, interaction and social context, to explore the relationship between language and ideology. So, it can be concluded that are (i) the theme and rheme can help organize messages and play an important role in the headlines from the perspective of the reader, (ii) BTP was explicitly represented as a social actor in some negative ways in those hoax news headlines such as not Pro-Islam, fails to eradicate prostitution, powerful person, not brave and involved in law case, (iii) the media's ideological stance intentionally contradicted to other national media in publishing the hoax news headlines related to BTP and tended to highlight the news without the clear sources and exaggerate the headlines.

\section{REFERENCES}

Amelda, R. (2018). Representasi Basuki Tjahaja Purnama (Ahok) Dalam Proses Pemilihan Gubernur DKI 2017 (Sebuah Studi Analisis Wacana Kritis) Di Mediaindonesia. Com. Bandung: Universitas Pendidikan Indonesia.

Badara, A. (2012). Analisis Wacana: Teori. Metode, dan Penerapannya pada Wacana Media.

Badara, A. (2014). Analisis Wacana: Teori. Metode, dan Penerapannya pada Wacana Media. Prenada Media.

BBC. (2017, May 9). https://www.bbc.com/news/world-asia. Retrieved from www.bbc.com: https://www.bbc.com/news/world-asia-37872151

Chiapello, E. \&. (2002). Understanding the new management ideology: a transdisciplinary contribution from critical discourse analysis and new sociology of capitalism. Discourse \& society,, 13(2), 185-206.

Fairclough, N. (2003). Analysing discourse: Textual analysis for social research. London: Psychology Press.

Fairclough, N. (2013). Critical discourse analysis. London: Sage.

Halliday, M. A. (2014). An introduction to functional grammar. Routledge.

Heberle, V. \&. (2016). Discussing the representation of immigrants: An integrated view from SFL, CDA and Multimodality. International Journal of Language Studies, 10(2), 61.

Mogashoa, T. (2014). Understanding critical discourse analysis in qualitative research. International Journal of Humanities Social Sciences and Education, $1(7), 105$.

Paltridge, B. (2012). Discourse analysis: An introduction. London: Bloomsbury Publishing.

Rolnicki, T. E. (2008). Pengantar Dasar Jurnalisme (Scholastic Journalism). Jakarta : Kencana Prenada.

Santosa, R. (2016). Critical Discourse Analysis (CDA): Systemic Functional Linguistics (SFL. PROSIDING PRASASTI, (p. 46). 
Setyaningsih, T. (2017). Wacana Pemberitaan Penista Agama oleh Basuki Tjahaya Purnama dalam harian Republika. Surakarta: UIN Surakarta.

Shojaei, A. Y. (2013). A CDA Approach to the Biased Interpretation and Representation of Ideologically Conflicting Ideas in Western Printed Media. Journal of Language Teaching \& Research, 4(4), 860.

Tulus, S. (2017). Wacana Pemberitaan Dugaan Penistaan Agama Oleh Basuki Tjahaja Purnama (Ahok)"(Analisis Wacana Kritis Norman Fairclough Pada Berita di Headline Surat Kabar Republika). Dissertation. Surakarta: IAIN.

Yousefi, M. H. (2019). A Critical Discourse Analysis of the Representations of Females in Printed Advertisements (Case Study of Payame Yaghoot Medical Health Iranian Journal). he Journal of Applied Linguistics and Applied Literature: Dynamics and Advances, , 7(1), 38. 